\title{
上腕骨々幹部骨折に対する骨接合術の治療経験
}

——Ender nailling 法を中心にして——

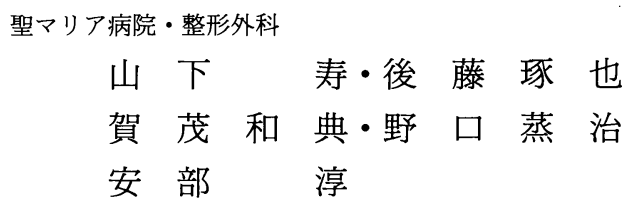

\section{Experience of Osteosynthesis in Fractures of the Shaft of Humerus with Ender Nailling}

by

\author{
Hisashi Yamashita, Takuya Goto, Kazunori Kamo \\ Johji Noguchi and Jun Abe
}

Department of Orthopedic Surgery, St. Mary Hospital Fukuoka, Japan

Out of 59 humeral shaft fractures in patients, 27 fractures were treated by Ender nailing. the Ender nails were inserted from the proximal or the distal humerus, or from both sides.

No infection, mal-union or non-union occurred but one case of postoperative radial nerve palsy which was followed by reconstructive intervention.

Backing out of the nail developed in 5 cases, requiring early removal of the nail.

Bony union occurred in all cases who underwent immediate closed pinning, and the excellent and satisfactory clinical results were obtained in $90 \%$ of the cases.

は じめに

上腕骨々幹部骨折は比較的骨瘾号は良好とされてお り, 治療は Coldwell の Hanging cast 法以来, 主と して保存的治療が行われてきた。

しかし実際には遷延治瘾や偽関節の発生することも あり, また長時間の外固定の苦痛, 頻回にわたるX線 コントロールによる被曝, 外固定除去後の関節拘縮も 問題となる.さらに近年は交通外傷の増加に伴う多発 骨折, 多発外傷や高齢化社会による老人骨折症例も増 加している．このような症例に対しては従来の保存的 治療では困難なことが多く, 我々は積極的に骨接合術 を行ってきたので今回は近年多用している Ender 法 による閉鎖性髄内固定例について検討したので報告す る.

\section{症例および結果}

昭和 57 年より平成元年までの 15 才以上の上腕骨々 幹部骨折 58 例 59 骨折であり性別は男性 36 例, 女性 22 例, 年令は 17 才〜 89 才平均 40.9 才であり, 開放性 骨折を 8 例に認めた。

治療法は保存的治療 15 例, 観血的治療 43 例 44 骨折 であり, 観血的治療法は Ender 釘による髄内固定法

（以下 Ender 法と略す） 27 例，Rash pinによる髄内 固定法 5 例, 内副子固定 10 例 11 骨折, 創外固定 1 例 であった（表 1).

以後, Ender 法による治療を行った 27 例について検 討を加える.

【受傷原因】交通外傷 14 例, 転落 5 例, 転倒 2 例, スポーツ, 労働災害, 不明各 1 例, 病的骨折 3 例とな 
表 1 症例

\begin{tabular}{|c|c|c|c|c|}
\hline \multicolumn{5}{|c|}{ 症例：58例 59 骨折 } \\
\hline \multirow{3}{*}{$\begin{array}{c}\text { 症例 } \\
\text { 性 } \\
\text { 年令 } \\
\text { 分類 }\end{array}$} & 男性36例 & \multicolumn{3}{|c|}{ 女性22例 } \\
\hline & 17〜 89才 & \multicolumn{3}{|c|}{ (平均 40.9 才) } \\
\hline & 解放性骨折 & \multicolumn{3}{|c|}{8 例 } \\
\hline & 閉鎖性骨折 & 50 例 & 51骨扩 & \\
\hline \multirow[t]{6}{*}{ 治療 } & 保存的治療 & 15例 & & \\
\hline & 観血的治療 & 43例 & 44骨护 & \\
\hline & Ender法 & & 27例 & \\
\hline & Rush pin & & 5 例 & \\
\hline & 内副子固定 & & 10例 & 11骨折 \\
\hline & 創外固定 & & 1 例 & \\
\hline
\end{tabular}

つており，压倒的に交通外傷によるものが多かった。 【合併損傷】脳挫傷 5 例, 腹腔内臟器損傷 2 例, 骨盤 骨折 2 例，脊髄・脊鹃道損傷 2 例，鎖骨・助骨骨折 5 例・ 下肢骨折 14 例, 上肢骨折 5 例の合計 35 例であり，多 発骨折, 多藏器損傷が 12 例 (44.4\%) と重度外傷の占 める比率が高かった。

【骨折部位】上 $1 / 3$ 骨折 4 例，中 $1 / 3$ 骨折 20 例，下 $1 / 3$ 骨折 3 例であった。骨折型は横骨折 15 例, 斜骨折 7 例, 螺旋骨折 3 例, 分節型骨折 2 例であった. Ender 法の最も良い適応とされる中 $1 / 3$ の横骨折が 14 例と 半数以上を占めた。

【刺入部位】大結節より $2 \sim 3 \mathrm{~cm}$ 末梢の上腕二頭 筋腱の外側より刺入する antegrade 法, fossa ore cranii中枢側約 $1.5 \sim 2 \mathrm{~cm}$ より刺入する retorograde 法，両顆部より刺入する epicondyle 法及び，その併 用を行っている. antegrade 法 10 例, retorograde 法 7 例, epicondye 法 1 例, 併用 9 例であった（図 1 ).

【術後合併症】感染症，nail 折損例は認めなかった が, nail の back outは 5 例にみられ， antegrade 法

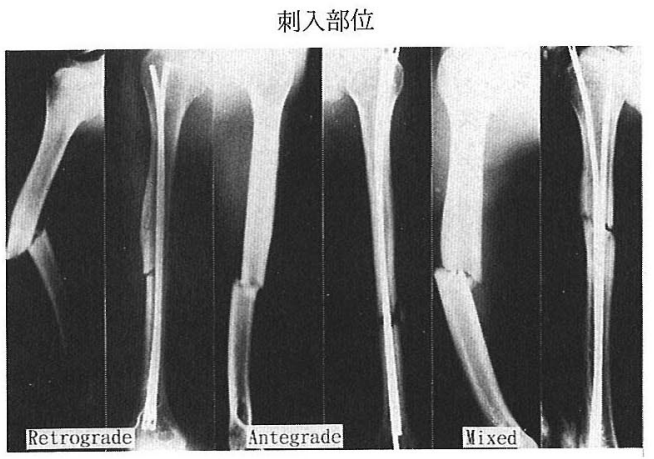

図 1

Endernail•の刺入法
の 4 例では, acromion との impingement による肩外 転障害, 運動時痛がみられ, retorograde 法の 1 例で は, fossa orecranii に突出した nail による肘伸展障害 がみられた。術後の橈骨神経麻痺は 1 例にみられ，こ れは術中の整復操作, 牽引によるものと考えられた。 術後 3.5 力月で neulolysis を施行した際, 橈骨神経は 骨折部で callus 内に entrapされており完全に変性し ていたため, 術後 4 力月, Riordan 法による機能再建 術を施行した。

【成績】骨撚合は全例飞認められ，X-P 上及び臨床 上判断された時期は, 術後 6 週〜 16 週平均 8.1 週であ った。骨湶合時の alignment は, $10^{\circ}$ 以上の angulation を示した例は 1 例であった。術後 1 年以上経過観察し えた 20 例を Brumback らによる評価基準" をもとに 評価すると Excellent 7 例(35\%), Good 11 例(55\%), Poor 2 例（10\%）であり，ほほ満足のできるものであ った.

Poorの 2 例は, back out に起因するもので骨瘾合 後早期に抜釷を行ったが，肩関節に運動痛が残存した 症例であり，すべて antegrade 法によるものであった (表 2 )。

$$
\text { 考察 }
$$

上腕骨々幹部骨折の治療で, Böhler は観血的治療に よる偽関節の発生が比較的多く, 橈骨神経麻痺の可能 性もあると述べると共に，長管骨々幹部骨折の中で最 も問題が少なく，かつ容易に保存的治療が可能である として安易な観血的治療を戒めている2)。また Klenerman ${ }^{4}$ が美容的, 機能的 angulation $の$ 許容範囲 は, 前後 $30^{\circ}$ 側面 $20^{\circ}$ とするように, 本骨折は必ずしも 正確な alignment の獲得を必要としない。これらが,

表 2 総合評価

\begin{tabular}{|c|c|}
\hline Excellent： 7 例 & \\
\hline ROM；肩関節 & 健側との差が10度以下 \\
\hline 肘関節 & 屈曲, 伸展の合計が10度以下の減少 \\
\hline 疼痛；なし & \\
\hline : 11例 & \\
\hline $\mathrm{ROM}$ ；肩関節 & 外転 120 度以上 \\
\hline 肘関節 & 屈曲, 伸展の合計が20度以下の減少 \\
\hline 疼痛；なし & \\
\hline : 2 例 & \\
\hline 肩, 肘関節の & ずれか, 又は共に運動時痛を認め \\
\hline
\end{tabular}


表 3 Ender法の適応

1. 多発外傷, 多発骨折

2. 保存的に整復位保持が困難な例

3 . 保持的治療に協力が得られない例

4. 高令者

5 . 病的骨折

本骨折の多くは保存的に良好な成績が得られる する理由と思われる。しかし，私達は本法の適応を表 3 のごとき症例としているが，その中でも特に多発骨 折, 多発外傷の救急手術時や, 高令者, 病的骨折患者 の早期社会復帰を目的として積極的に Ender 法を行 っている.

Ender 法は，閉鎖性髄内固定が可能であり，骨折部 周囲の軟部組織，骨膜は温存され患者に対する侵襲は 比較的少なく，また手技も比較的容易であり semiconservative な治療が可能である.しかし, Ender 法の最 大の欠点は従来言われているように牽引力，回旋力に 対する固定性が不十分な点である.しかしこれは術後, 関節拘縮の原因とならない程度の簡単な外固定を行う ことで補うことができると考えている．また閉鎖性の ため術中の神経血管障害を確実に避けることは不可能 であり, 術中整復の際, 頻回にわたる整復操作は避け, 整復困難な場合はいつでも open reduction できる準 備が必要である. 最後に最も問題となる nail の back out よる疼痛と機能障害であるが nail の太さと本数 の調整で，ある程度対処できると考えられる．刺入部 位に関しては，我々の症例では少なかったが，諸家の 報告 ${ }^{1)}$ では最も有痛性可動域制限が多くみられるとさ れる epicondyle 法はできるだけ避け, antegrade 法は
下 $1 / 3$ の骨折に限定し, 行う場合は rotator cuff の外 側より刺入することで減少させられるのではないかと 考えている.

\section{結語}

1. Ender 法を行った上腕骨々幹部骨折 27 例につ いて検討した。

2. 全例に骨癒合が得られており，機能的に予後不 良の症例は nail の back outに起因するものであっ た.

3. Ender 法による閉鎖性髄内固定は，比較的手技 も容易であり症例を選べば，上腕骨々幹部骨折に対し て有効な治療法であると思われた。

\section{文}

\section{献}

1) Brumback, R. J, Poka, A. and Burgess, A. R, : Intramedullary stabilization of humeral shaft fractures in patients with multiple trauma. J. Bone Joint Sure., 68-A, 960-969, 1986.

2) Böhler, L. : Conservative treatment of fresh closed fracture of the shaft of the humerus. J. Trauma, 5: 464-468, 1965

3) Crenshow, A.: Cambell's Operative Orthopedics, 6th ed., 670, C. V. Mosby, St. Louis. 1980.

4) Klenerman, L.: Fractures of the shaft of the humerus. J. Bone Joit Sure. 48-B (1) : 105-111, 1966.

5) Robert, F. H. Jr. and Pankovitch, A. M. : Ender nailing of acute fracture of the humerus. J. Bone Joint Surg. 69-A, 558-567, 1987

6) Stewert, M. J, et al : Fractures of the humerus. A comparative study in methods and treatment. J. Bone Joint Surg., 37-A, 681, 1955. 